\title{
Does Pythagoreanism Really Belong to Greek?
}

\author{
Sunkanna Velpula \\ Department of Philosophy, University of Hyderabad, Hyderabad, India \\ Email address: \\ sunkannahcu@gmail.com
}

\section{To cite this article:}

Sunkanna Velpula. Does Pythagoreanism Really Belong to Greek? International Journal of Philosophy. Vol. 4, No. 2, 2016 , pp. 7-10. doi: 10.11648/j.ijp.20160402.11

Received: December 31, 2015; Accepted: February 3, 2016; Published: April 27, 2016

\begin{abstract}
Pythagoras of Samos was the founder of the religious movement called Pythagoreanism and also well known Philosopher and mathematician. We have very little reliable information about Pythagoras from the secondary sources because he personally wrote nothing though hecould inspire legends. That is why Aristotle also often referred to the Pythagoreans but not to Pythagoras as such. Historically Pythagoras is being treated as the first mathematician, the first philosopher and the first metempsychosist. But there are certain doubts on the authorship of Pythagoreanism. Is it really proposed by Pythagoras? Some believes that he was not the author of Pythagoreanism because the Pythagorean principle was very much present in $10^{\text {th }}$ century $\mathrm{BC}$ in China and $9^{\text {th }}$ century $\mathrm{BB}$ in India. This paper examines the evidences and tries to analyze the authorship of Pythagoreanism.
\end{abstract}

Keywords: Pythagoreanism, Divine-Fire, Divine-One, Bhāskara, Śulbasūtras, Baudhāyana, Orphic

\section{Introduction}

Pythagoras of Samos was the founder of the religious movement called Pythagoreanism and also well known Philosopher and mathematician. We have very little reliable information about Pythagoras from the secondary sources because he personally wrote nothing though hecould inspire legends. That is why Aristotle also often referred to the Pythagoreans but not to Pythagoras as such. Historically Pythagoras is being treated as the first mathematician, the first philosopher and the first metempsychosist. [1] It is not just because he was the first person to use numbers, not because he was the first person to seek a rational explanation of the world and not because of the first person to believe that the soul is immortal but because of the belief that all Pythagorean concepts began from Pythagoras. He is well known for his mathematical theory the Pythagorean Theorem. Though he is being recognized as the first mathematician but there is no certainty in one thing that whether he was the first person to propose the Pythagorean Theorem. It would help us in understanding the origin of the Pythagorean Theorem if we understand his notion of the soul before entering into main discussion. Like some prePythagorean philosophers, Pythagoras also followed the Orphic traditions and carried the practice of purifying the soul and also suggested a deeper idea of what such purification might be. Pythagoreans believed that physical sensuality contaminates the soul; the noblest means of purification is intellectual activity which liberates the soul. For Pythagoreans, purification partly consisted in the observance of ascetic rules of abstinence from certain kinds of food and dress and intellectually, the purification of the soul by the contemplation of the divine order of the world which includes the mathematical activity.

\section{Pythagorean Theory of Evolution}

While his contemporaries, Anaximander and Anaximenes, tried to demonstrate the nature of the supreme divine power in their philosophical ways, Pythagoras demonstrated it through the mixture of religious, philosophical and scientific ways. Pythagoreans are not only known for their theory of the transmigration of the soul but also for their theory that numbers constitute the true nature of things which is connected with the human life and the universe at large. The way Anaximenes proposed divine Air as the cause of an apparent diversity in the same way Pythagoras proposed divine Fire as the cosmogenetic God, the source of immortal life and the substance of the universe. But there is a twist, "Pythagoras identified the divine Fire with the divine One 
and by this puzzling identification of substance with number caused endless trouble to all who attempt to understand Pythagoreanism without being Pythagoreans. "[2] The One seemed to Pythagoras to have inexhaustible power and was like the Infinite and Indeterminate of Anaximander. The One is an affirmation of divine causal unity set against the plurality of changing things within the cosmos. When Pythagoras declared that the supreme God was the One, he did not in the least intend to deny that the supreme God was Fire and was the source of all life and of the universe. The One was the source of all unity as well as the first cause of all numbers and the determining principle in all diversity. [3] Here the Pythagorean concept of One resembles Anaximander's principle of Infinite since the Pythagoreans One too infinite and indeterminate. According to Pythagoras the One is Fire and the One Fire is forming the Universe. It explains all the phenomena that come into being in the universe.

On Earth we men are imprisoned, being surrounded by bodies, by constant change and imperfection; but we have Life (Psyche) within us, and are therefore akin to the One Fire. The purest part of the Life or soul within us is Mind or reason, and we may speak of it as a fragment of the One which is the source of all order. [4] Mind has been treated as part of the divine One and the source of knowledge. The One thus binds and produces order. Our souls are immortal but the portion of the One that they contain is too feeble to make this binding with our bodies permanent. Its dissolution is the 'release' in death. If we consider all these saying of Pythagoras in the pure philosophical sense, the One which was seen as Fire, as well as the supreme God, will appear as pure substance. But some philosophers say that the Pythagorean Fire is going away from the substance theory and towards the theory of causality. The One does not grow, but it is the cause of growth. It does not change, but it is the cause of change. Another important thing which Pythagoras comprised is that our supreme God is the One Fire; the Stars, the Planets, and the Sun are clearly of kindred Fire, and are the principal subordinate Gods; they dwell in a pure region, where there is less change and life is more nearly perfect. [5]

The most important thing that we have to keep in our minds is that the soul is incorporeal in nature and that is a spiritual entity. For Pythagoras the doctrine of the soul explains the spiritual nature of man. All souls come from the One divine source and runs through all human forms of life. Each soul involved in the conflict of good and evil seeks to escape from the purgatorial round of lives and deaths into a better world of unity and rest. If Body is capable of having life could serve as the home of soul and the soul comes from the divine and returns to the divine. Pythagoras and early Pythagoreans used the Psyche to refer to the transmigrating soul, the soul that is the center of the personality during life. They believe that the soul after withdrawing from one Body will transmigrate into another. The activity of transmigration will go on as long as the soul has bodily attachments and worldly desires. But there is a possibility to overcome the wheel of transmigration. "The power of mental concentration, and of metaphysical abstraction, are therefore the highest intellectual gifts, and quietism, or the absorption of our nature in God, is the last stage of virtue. 'The end of man, 'said Pythagoras is God." [6] On the basis of the above reference also we can establish the end of the man is God and the purity of the soul means making itself like the One supreme God, who is perfect purity. In this way there will be possibility for soul to attain purity. There is another reference which indicates the immortality of the soul; "Our Souls are deathless; when they leave their former home, always new habitations welcome them to live afresh." [7] The wheel of transmigration is to help the soul to become pure to join with the perfect purity that is One supreme God. But after the transmigration whether it will get higher order life or lower order life will depend on the purity of the soul. Every entrance of the soul into a Body is a punishment imposed by the One supreme God, and resembles entrance into a tomb or a prison; if the soul fails in purity, it may be sent into the Body of a lower animal, and if its failure be grave, it will undergo especial punishment in Hades.

The way Indian philosophical schools turned as religious sects, in the same way ancient Greek philosophical schools either established on religious grounds or turned as religious movements because the influence of religion was in high degree. At the same time the philosophical way of explaining man was very close to the religious explanations. Pythagoras, as the founder of the religious movement, has come up with a new practice of dividing the soul; "he originated the doctrine of the tripartite soul, which resurfaced in the philosophy of Plato." [8] Whether it was the division of man (mental and material combination) or the division of only mental entity is not clearly mentioned anywhere. But some references indicate that it is the division of man as Mind (Nous), Body (Soma) and Soul (Psyche). Not only the division but also the attributes of the Mind, Body and Soul are shown such as that the Soul as psychic faculty, Mind as the rational faculty and the Body as having sensations and thought. He believed, like the Indians, that only by purifying the soul we can attain divine powers and at the end merge with divinity. Hence, he insisted that a disciple should first be formally initiated by a preceptor who himself must be pure so that he can impart knowledge to others. Pythagoras taught that the study and the contemplation of the universe is the supreme religious duty of man, it was the means by which man could become like God. Pythagoras performed purification rites and also followed and developed various rules of living which they believed would enable their souls to achieve a higher rank among the Gods. As a prophet of God and a spokesman of Apollo, Pythagoras turned philosophy totally into a mystery religion that can be clearly seen in all that is known of his life and of his doctrines. Much of his mysticism concerning the soul seems inseparable from the Orphic tradition. The whole school of Pythagoras made chastity one of its leading virtues, and even labored for the creation of a monastic system. [9] That's why the whole school of Pythagoras objected to sacrifices. [10] 


\section{Pythagorean Theorem}

When it comes to the matter of the authorship of the Pythagorean Theorem then there is uncertainty. When we talk about his notion of the soul, as I have discussed, it seems that it not only involves pre-Pythagorean religious notions but also Indian religious notions. His mathematical theorem also not exempted because Pythagorean Theorem was known long before Pythagoras. Three doubts will be raised in our mind when we talk about Pythagorean Theorem; at first, whether Pythagoras was Greek or Chinese? Secondly, if he was not Chinese then who was the author of Pythagorean Theorem? Thirdly, whether he learned it from India? There are strong evidences to prove that the Pythagorean Theorem was known to this world long before Pythagoras. It was available in ancient China before $6^{\text {th }}$ century $\mathrm{BC}$ that is why the first doubt arises, "whether Pythagoras was Greek or Chinese?" Some evidences show that, "He was not even the first to discover it: the theorem had been known to the Babylonians, and to the Chinese, at least a thousand years before him." [11] There are good evidences to show that the mathematical theorem (which is known to this world as Pythagorean Theorem) first appeared in the Chiu Chang Suan Shu [12] which was the most important mathematical books in China; it includes the mathematical history of Chinese from 1261 BC. Some other says that the Pythagorean Theorem has been known in China as the $\mathrm{Kou}-\mathrm{Ku}$ (right angles) theorem and it appears in numerous problems in Chinese writings. [13] It is also said that, "The problem of the Kou-ku of the Chiu Chang indicates that the Chinese had accumulated a wealth of experience in working with the right triangle in various mathematical situations well before the Christian era." [14] Even the hsuan-thu diagram of the Chou pei represents the oldest recorded proof of the Pythagorean Theorem. That's why the author of "Was Pythagoras Chinese?" finally says that the authorship of the Pythagorean Theorem is indisputably Chinese. He also declares that if we now scrutinize the claim for Pythagorean authorship of the theorem that bears that name, we find that it rests mainly on tradition - a tradition that is founded on the realization that much of western societies' ethical, political, philosophical, and early scientific theories originated in the eastern Mediterranean region.

When it comes to the question, Does Pythagoras learn it from India? Then there are some evidences to support this argument. The historian of ancient Greek mathematics Thomas Heath states that this type of proof was alien to Greek geometrical methods and modes of thinking. He expressed the doubt that this mathematical theorem might have been developed outside the Greek and Greeks might have adopted it at the earliest stage. Swetz and Kao state that, "it is known to have appeared in the works of the Indian mathematician Bhāskara in 1050 BC." [15] That's why if we go back into the history of Eastern mathematics, through some available evidence, it seems that Bhāskara was influenced by ancient Chinese mathematical works. [16] The earliest Hindu writings on mathematics were an offspring of
Hindu religious practices. A group of writings known collectively as the Ślbasutras deal with the dimensions of sacrificial altars (vedi), a subject of great importance in Hindu religion. One of these Śulbasūtras, by an author named Baudhāyana, dates back to perhaps 600 BC or earlier, to the time of Thales, gives instructions on how to square $a$ rectangle (how to construct a square equal in area to a given rectangle which resembles Pythagorean Theorem). The later Ślbasūtras of Kätyāyana states the similar theorem. There are instructions in the Ślbasūtras on how to construct a square whose area is the sum of two given squares. [17] After observing all of these evidences we can estimate that Indians also had the knowledge of the Pythagorean Theorem at least as early as Pythagoras. These evidences show that Pythagoras might have learned it either from India or China. Some other says that, although Pythagoras may not have travelled as far as Persiaor India, he may well have become aware of the teachings of the Brahmins when passing through Phoenicia on his way to Babylon [18] because there are number of evidences to show that he visited Babylon. Some others says that, "he has been prolonged for nearly thirty years, to visit the Arabians, the Syrians, the Phoenicians, the Chaldeans, the Indians, and the Gallic Druids." [19] Another thing is that the Pythagorean Theorem was not in use for five hundred years after the death of Pythagoras. It was Cicero and Plutarch who attributed the theorem to Pythagoras; though, according to Sir Thomas L. Heath, there is no attribution by Pythagoras himself during his lifetime.

\section{Conclusion}

My purpose here is not only finding out who was the author of the Pythagorean Theorem but also understanding how the radically different civilizations in India, China and Greece regarded right triangles in a remarkably similar way. In case of Pythagoras the similarity was there not only in mathematics but also in religious and philosophical aspects. The concept of transmigration of the soul was not an alien notion for Indian philosophical as well as Hindu religious systems. What I want to remind here is that, as M.E. Pococke shows in his book India in Greece, the Hindu thought also showed a great influence on Greek thought. It is believed that besides Pythagoras, Appolonius, Democritus, Anaxarchus and Pyrrho also visited India. According to some other philosophers, the Golden Philosophy first descended upon "the Indians, the mightiest nation upon the earth." The central purpose of Pythagoras was to purify the soul of man and to guarantee a happy immortality by a special discipline. As I have already mentioned, Pythagoras and Pythagoreans held the doctrine of metempsychosis, as the Hindus do the same tenet, of the transmigration of soul. [20]

\section{References}

[1] Metempsychosis is a philosophical term in the Greek language referring to transmigration of the Soul. 
[2] Roy Kenneth Hack, God in Greek Philosophy To the Time of Socrates (Princeton: Princeton University Press, 1969), p. 48.

[3] Ibid, p. 50.

[4] Ibid, p. 53.

[5] Ibid, p. 53.

[6] William Edward Hartpole Lecky, History of European Morals from Augustus to Charlemagne, Vol. 1(New York: D. Appleton and Company, 1869), p. 347.

[7] Charles H. Kahn, Pythagoras and Pythagoreans: A Brief History (Indianapolis/Cambridge: Hackett Publishing Company, Inc. 2001), p. 147.

[8] Raymond Martin \& John Barresi, The Rise and the fall of Soul and Self (New York: Columbia University Press, 2008), p. 10.

[9] William Edward Hartpole Lecky, History of European morals from Augustus to Charlemagne, Vol. 1 (New York: D. Appleton and Company, 1869), p. 109.

[10] Ibid, p. 167.
[11] Eli Maor, The Pythagorean Theorem (Princeton and Oxford: Princeton University Press, 2007), p. xi.

[12] It was translated into English as "Nine Chapters on the Mathematical Art."

[13] Eli Maor, The Pythagorean Theorem (Princeton and Oxford: Princeton University Press, 2007), p. 64.

[14] Frank J. Swetz and T. I. Kao. Was Pythagoras Chinese? (University Park: The Pennsylvania State University Press, 1988), p. 66.

[15] Ibid, p. 14.

[16] Ibid, p. 14.

[17] Eli Maor, The Pythagorean Theorem (Princeton and Oxford: Princeton University Press, 2007), p. 67.

[18] Paul Strathern, Pythagoras \& his Theorem (London: Arrow, 1997), p. 23.

[19] Edward Pococke, India in Greece; or, Truth in Mythology (London: John J. Griffin and Co., 1852), p. 353.

[20] Ibid, p. 363. 